\title{
Morris M. Faierstein, Trans. and Ed. Yudisher Theriak: An Early Modern Yiddish Defense of Judaism
}

(Detroit: Wayne State University Press, 2016), hardcover, x + 180 pp.

\author{
JOSHUA JOHNSON \\ joshua.a.johnson@wsu.edu \\ Washington State University, Pullman, WA 99164
}

In the early Modern Period, as in previous periods, many Christians composed anti-Jewish tracts. Samuel Friedrich Brenz's Jüdischer abgestreiffter Schlangenbalg ("The Jewish Shed-off Snakeskin"), published in Nurenberg and Ausgburg in 1614, is but one example of this genre, and not itself noteworthy. However, it prompted Zalman Zvi, a Jew from Aufhausen, to compose a detailed refutation, Yudisher Theriak ("Jewish Antidote"). This latter work is unique as the only book published in Germany and written in a form of early modern Yiddish that responded to an anti-Jewish attack. This translation by Morris M. Faierstein is therefore to be welcomed.

In his epilogue, Zvi states he writes for Christians, which may account for the Germanized dialect. However, this statement seems to be at odds with his repeated references to another book he wrote that, he says, was intended for Christians, implying that he intended the Theriak to be a sort of handbook for Jewish apologetics. Zvi, perhaps because he personally knew Brenz, who was a Jewish convert to Christianity, presents a vigorous, line-by-line rebuttal of Brenz's views. Zvi considers Brenz's vitriol so caustic that he never even calls him by his name "Samuel," but rather repeatedly refers to him as "Samael," a Midrashic name for the satan, and as "the apostate."

Brenz makes a number of claims about Jewish hostility to Christians and Christianity, to which Zvi responds. Brenz accuses Jews of wanting to harm their Christian neighbors, of seeking to overthrow Christian government, and, on the tamer end, of not patronizing Christian businesses. For his first assertion he cites the biblical command that the Israelites kill the pagans in the land of Israel. Zvi responds that these claims are impossible. For example, Jews depend on Christians for food, as Jews were not allowed to farm. Also, Jews need simple services from those such as barbers and physicians, who are mostly Christians. Jews do not seek to overthrow the government because to do so would be to disobey God. Rather, they pray for kings, dukes, and other leaders. Also, the pagan nations in the Hebrew Bible no longer exist. Therefore, to apply these verses to modern-day goyyim is wrong and irresponsible. Finally, Zvi uses the 
rabbinic idea of shituf to argue that even though Christians believe in the Trinity, they still worship one God and are not pagans. Such a belief does not undermine their claims to be monotheists, though this is not acceptable for Jews.

While Brenz often draws upon Jewish sources, he appears to know little about Judaism or Hebrew. Zvi, on the other hand, scrupulously checks all of Brenz's allegations and finds that most have no basis in any source at all. Zvi cites every source he uses, whether it is the Talmud, Rabbinic responsa, or the Hebrew Bible. Zvi even cites the New Testament to show that Brenz barely knows this work. The picture of Brenz that emerges in Zvi's book is of a fool, unable to understand, or even correctly quote, a source. Zvi is lead to wonder how Brenz, though raised a Jew, could not even remember Hebrew prayers.

Morris Faierstein discusses Zvi's Yiddish, which, he notes, is of a Germanizing tendency. An example of this Germanized Yiddish can be seen in the title itself. A pure Yiddish title would be Yidisher Theriak. However, Yudisher Theriak is patterned after German Jüdischer. The differences are not significant, but it is interesting that Zvi wrote in a more Germanized dialect, and also that he could read German, which was unusual for a Jew of his time and place.

This book will not only interest scholars of early Modern Germany, but scholars of Christian-Jewish relations generally. Faierstein's translation of Zvi's work - the first time it has been published in English - gives this book great value. In addition to an introduction and the translation itself, the volume includes a list of Brenz's accusations, appendices on the publication history and of citations of the writings of Josephus, a bibliography, an index of citations, and a general index. 